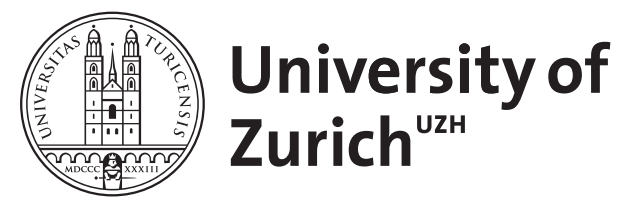

\title{
7.18 Long-Runout Landslides
}

\author{
Korup, Oliver ; Schneider, Demian ; Huggel, Christian ; Dufresne, Anja
}

\begin{abstract}
This chapter provides an overview of large $\left(>10 \mathrm{~m}^{3}\right)$ volcanic and nonvolcanic long-runout landslides characterized by high velocities, large release and deposit volumes, and excess runout. Large long-runout landslides are very rare events and pose substantial challenges to quantitative hazard assessments. Despite several mechanistic theories, there is no commonly agreed-upon explanation of excess runout, which would also entail superposition of processes such as dynamic fragmentation, material bulking, and partial lubrication. Water as a lubricant plays only a minor or limited role given the ample evidence of dry excess runout. Numerical models based on shallow water equations provide some of the best means to realistically simulate rapid flow- and avalanche-like motion over three-dimensional terrain. However, such models critically depend on reliable initial conditions, such as failure volume and scar, material properties, and runout topography.
\end{abstract}

DOI: https://doi.org/10.1016/B978-0-12-374739-6.00164-0

Posted at the Zurich Open Repository and Archive, University of Zurich

ZORA URL: https://doi.org/10.5167/uzh-86048

Published Research Report

Published Version

Originally published at:

Korup, Oliver; Schneider, Demian; Huggel, Christian; Dufresne, Anja (2013). 7.18 Long-Runout Landslides. Amsterdam: Elsevier.

DOI: https://doi.org/10.1016/B978-0-12-374739-6.00164-0 
Journals Books Register Sign in

Subject Browse Article Outline
Earth Systems and Environmental Scie
Atmospheric Sciences
Bioscience
Energy and Natural Resources
Geosciences
Earth History
Earth Surface Processes
Earth Surface Fluid Flow and Sedime
Geomorphology
Glacial Processes and Landscapes
Hillslope Processes
Hillslope Mass Movement
Hillslope Settings
Physical Hillslope Processes
Marine Processes and Landscapes
Rivers and Lakes
Soils
Weathering and Erosion
Wind Processes and Landscapes
Geochemistry
Geology
Geophysics
Global Change
Hydrology
Oceanography
(a)

ADVERTISEMENT
Purchase Export Search ScienceDirect $\mathbf{Q}$ Advanced search

Reference Module in Earth Systems and

Environmental Sciences

Treatise on Geomorphology

2013, Pages 183-199

Volume 7

\subsection{Long-Runout Landslides}

Current as of 26 February 2015

Show more

Choose an option to locate/access this article:

Check if you have access through your login credentials

Purchase

Check Access Options or your institution

Get Full Text Elsewhere

Check Access

https://doi.org/10.1016/B978-0-12-374739-6.00164-0

Get rights and content

\section{Abstract}

This chapter provides an overview of large $\left(>10^{6} \mathrm{~m}^{3}\right)$ volcanic and nonvolcanic long-runout landslides characterized by high velocities, large release and deposit volumes, and excess runout. Large long-runout landslides are very rare events and pose substantial challenges to quantitative hazard assessments. Despite several mechanistic theories, there is no commonly agreed-upon explanation of excess runout, which would also entail superposition of processes such as dynamic fragmentation, material bulking, and partial lubrication. Water as a lubricant plays only a minor or limited role given the ample evidence of dry excess runout. Numerical models based on shallow water equations provide some of the best means to realistically simulate rapid flow- and avalanche-like motion over three-dimensional terrain. However, such models critically depend on reliable initial conditions, such as failure volume and scar, material properties, and runout topography.

\section{Keywords}

Basal friction; Catastrophic landslide; Dynamic fragmentation; Fluidization; Landslide dynamics; Landslide mobility; Pore pressures; Rock avalanche; Runout; Volcanic debris avalanche

it Korup, O., Schneider, D., Huggel, C., Dufresne, A., 2013. Long-runout landslides. In: Shroder, J. (Editor in Chief), Marston, R.A., Stoffel, M. (Eds.), Treatise on Geomorphology. Academic Press, San Diego, CA, vol. 7, Mountain and Hillslope Geomorphology, pp. 183-199.

Vitae 


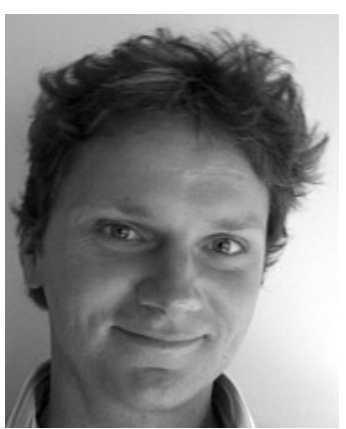

Oliver Korup is a geomorphologist interested in quantitatively studying the coupling of Earth surface processes in active mountain belts. This entails investigating feedbacks with tectonic, climatic, and anthropogenic processes, and has direct applications for understanding landscape evolution and appraising natural hazards.

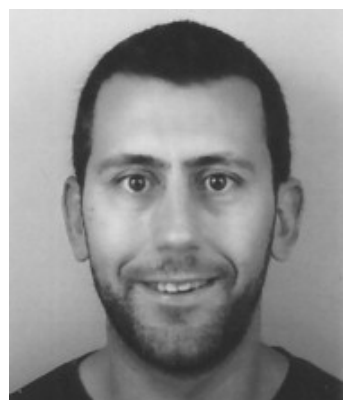

As a physical geographer, Demian Schneider is specialized on natural hazards, particularly on rapid mass movements in glacial and volcanic mountain environments. His focus is on enhancing the understanding of process interactions in a changing landscape as a key to improve hazard mapping and mitigation measures.

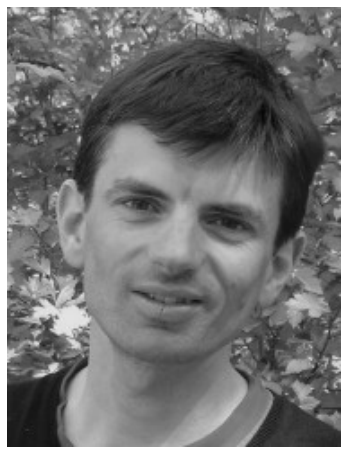

Christian Huggel has a $\mathrm{PhD}$ in physical geography. $\mathrm{He}$ is a senior scientist at the University of Zürich as well as at the University of Geneva. His research interests are in climate change impacts in high mountains, associated hazards and risks, as well as adaptation and prevention thereof.

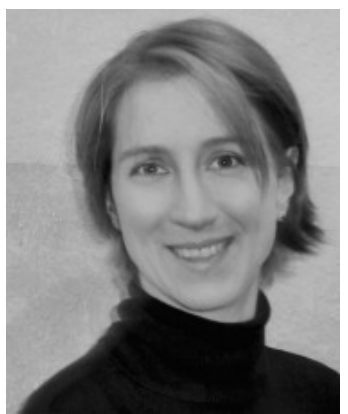

Anja Dufresne is a geoscientist interested in the processes of rapid geomorphological changes within mountainous terrains. A central focus of her research is the application of laboratory analog models to investigate the processes and influencing factors, particularly of runout path materials, involved in rock-avalanche emplacement.

Copyright $@ 2013$ Elsevier Inc. All rights reserved.

Reference articles on "Hillslope Mass Movement"

7.23 Mass-Movement Causes: Earthquakes

2013, Reference Module in Earth Systems and Environme... more

7.26 Mass-Movement Hazards and Risks 
Runout Landslides - Reference Module in Earth Systems and En... https://www.sciencedirect.com/science/article/pii/B9780123747..

2013, Reference Module in Earth Systems and Environme... more

7.28 Numerical Modeling of Flows and Falls

2013, Reference Module in Earth Systems and Environme... more

View more articles »

Recommended articles

Citing articles (0)

Related book content 
Runout Landslides - Reference Module in Earth Systems and En... https://www.sciencedirect.com/science/article/pii/B9780123747... 